\title{
BAGIAN WARIS BAGI JANDA DALAM HUKUM KEWARISAN ISLAM DAN KOMPILASI HUKUM ISLAM
}

\author{
Dwi Wulandari \\ Institut Agama Islam Negeri Kediri, Jawa Timur \\ Email: dwulandari932@gmail.com
}

\begin{abstract}
During this time, science Mawaris only studied in the Islamic legal literature, which is still general science. The distribution of inheritance follows what has been mentioned in the Qur'an and al-Sunnah and there are additions from the ijtihad results of the Companions in the Arab countries. The structure of Indonesian people's life which is different from the Arab community, makes the Islamic Inheritance Law appear rigid and difficult when applied in Indonesia, so that many Muslims in Indonesia prefer adat inheritance law. Through the literature study method, writing examines as well as disseminates information related to the Compilation of Islamic Law that is used to implement Islamic inheritance law in Indonesia that is not widely known by the public. Indonesian 'ulama who have studied mawaris, are trying to formulate Islamic inheritance law by considering the conditions of Indonesian society, so that this Islamic inheritance law can be accepted by Indonesian Muslims. The efforts of the 'ulama bore fruit with the birth of the Compilation of Islamic Law, even though its status is still the President's instruction and has not been made official as a law. But it has been applied in the Religious Courts and is disseminated and reviewed in tertiary institutions.
\end{abstract}

Keywords: Waris, Widows, Law, Islam, KHI.

\section{A. Pendahuluan}

Pada zaman penjajahan Belanda, implementasi hukum kewarisna Islam tidak berkembang. Sebab dalam proses pembagian harta waris, masyarakat lebih memilih menggunakan hukum adat dari pada hukum kewarisan Islam. Dalam pandangan mereka, hukum kewarisan Islam tidak memiliki sistem tertentu, sehingga menimbulkan sebuah anggapan bahwa hukum kewarisan Islam merupakan hukum yang rumit. ${ }^{1}$

Kondisi seperti inilah yang menyebabkan hukum kewarisan Islam menurut fiqh kebudayaan Arab itu sangat sulit diterima oleh masyarakat Islam di Indonesia.

Maka dibutuhkan formulasi penerapan konsepsi hukum Islam yang sesuai dengan struktur kehidupan masyarakat Indonesia. Walaupun hal ini nantinya akan menghasilkan perbedaan hasil ijtihad dalam penerapan hukum Islam di negeranegara Islam lainnya.

Mengutip dari pendapat $\mathrm{H}$. Abdurrahman $\mathrm{SH}, \mathrm{MH}$ yang menuturkan bahwa perbincangan tentang hukum Islam di Indonesia dengan hukum Islam diberbagai kawasan dunia akan selalu menampakkan dua wajah,yaitu wajah yang tampak sebagai hukum yang bersifat universal dengan daya jangkau untuk semua tempat

${ }^{1}$ Moh. Muhibbin dan Abdul Wahid, Hukum Kewarisan Islam Sebagai Pembaruan Hukum Positif di Indonesia (Jakarta: Sinar Grafika, 2019), h. 4. 
dan sepanjang zaman. Dan dibutuhkan pula wajah lainnya yang khas hukum Islam Indonesia masa kini. ${ }^{2}$

Penuturan selanjutnya disebutkan bahwa "Hukum Islam Indonesia masa kini" merupakan sebuah label yang diberikan pada ketentuan-ketentuan hukum Islam yang berlaku di Indonesia, sekaligus menampilkan corak khas Indonesia. Sistem dan budaya Indonesia akan lebih terefleksi didalam, sehingga hukum Islam dimaksudkan untuk beberapa bagian tertentu baik yang menyangkut kaidah hukumnya maupun pola pemikiran yang mendasarinya akan menunjukkan beberapa perbedaan dengan hukum Islam yang berlaku ditempat negara Islam lainnya, sekalipun memiliki sifat dasar yang sama yaitu bersumber pada al-Qur'an dan Sunnah. ${ }^{3}$

\section{B. Pembahasan}

\section{B.1. Hukum Kewarisan Islam}

Terdapat beberapa istilah lain dari hukum kewarisan Islam, yakni diantaranya fiqh mawaris atau ilmu miros dan ilmu faraid. Pada dasarnya perbedaan tersebut berada pada arah titik utama yang dijadikan pembahasannya saja. ${ }^{4}$ Bisa kita telusuri lebih dulu makna dari istilah-istilah tersebut.

Fiqh mawaris berasal dari dua kata, yakni fiqh dan mawaris. Fiqh secara bahasa memiliki makna paham dan mengerti. Adapun secara istilah syara', fiqh adalah mengetahui hukum-hukum syara' yang berkaitan dengan perbuatan manusia yang diambil dari dalil-dalil yang jelas dan terperinci. ${ }^{5}$

Sedangkan mawaris adalah bentuk jama' dari miros. Dan miros berasal dari bentuk masdar yang memiliki arti ketetapan harta yang dimiliki seseorang setelah meninggalnnya orang lain, yang mana ia bisa mengambil sisa dari apa yang ditinggalkan oleh si mayit (orang lain yang meninggal tadi). ${ }^{6} \mathrm{Atau}$ lebih mudahnya bisa dipahami sebagai harta peninggalan yang diwarisi oleh ahli waris.

Dijelaskan pula oleh Prof. Hasby as-Shiddiqi bahwa fiqh mawaris adalah ilmu yang digunakan untuk mengetahui orang-orang yang berhak memenerima warisan dan orang yang tidak berhak menerima warisan, serta kadar / bagian yang didapat oleh setiap ahli waris sekaligus tata cara pembagiannya. ${ }^{7}$

Sedangkan dalam literatur klasik, disebutkan oleh ulama' hanafiyah bahwa ilmu miros adalah kaidah-kaidah fiqih dan kaidah penghitungan yang digunakan untuk bisa mengetahui bagian yang diterima oleh ahli waris dalam hal harta peninggalan. ${ }^{8}$

2Abdurrahman, Kompilasi Hukum Islam di Indonesia (Jakarta: Akademika Pressindo, 1992), h. 4.

3Ibid., 5.

${ }^{4}$ Moh. Muhibbin dan Abdul Wahid, Hukum Kewarisan Islam..., h. 6.

${ }^{5}$ Muhammad al-Jurjani, Kitab al-Ta' rifat, (Singapore, Jeddah : al-Haramian), h. 168.

6 Wahbbah al-Zuhaili, al-Figh al-Islamy wa Adillatuh, (Damaskus: Dar al-Fikr, 2008), jilid 8, h. 241.

7Teungku Muhammad Hasbi Ash-Shiddieqy, Figh Mawaris, (Semarang: Pustaka Rizki Putra, 2001), h. 5.

${ }^{8}$ Amin Abdu al-Ma'bud Zaghlul, Ahkam al-Miras wa al-wasiyah fi Syari'ah al-Islamiyah, (Kairo: Nabil, 2009), h. 46. 
Adapun ulama' malikiyah memberikan makna yang hampir sama dengan prof hasby as-shiddiqi, yaitu ilmu yang digunakan untuk mengetahui orang-orang yang berhak memenerima warisan dan orang yang tidak berhak menerima warisan, serta kadar / bagian yang didapat oleh setiap ahli waris. ${ }^{9}$

Wahbah Zuhayli pun turut menjelaskan dalam bukunya al-fiqh al-Islamy wa adillatuh bahwa sebagian ulama' mengartikan ilmu miros merupakan ilmu yang bersumber dari fiqh dan penghitungannya yang mana kedua ilmu tersebut membahas tentang kekhususan pada setiap hak dari harta peninggalan. ${ }^{10}$

Dari penjelasan diatas bisa ditarik kesimpulan bahwa fiqh mawaris adalah suatu ilmu yang menjelaskan tentang harta peninggalan, proses pemindahannya, dan orang-orang yang berhak menerimanya sekaligus besar kecilnya bagian harta peninggalan yang diterima.

Sebagian ulama' menyebut fiqh mawaris dengan ilmu faraidh. Faraidh merupakan jamak dari faridhah yang berarti wajib, takaran, pasti, dan jelas. ${ }^{11}$ Penyebutan ilmu faraidh diambil dari ayat al-Qur'an surat al-nisa' ayat 7:

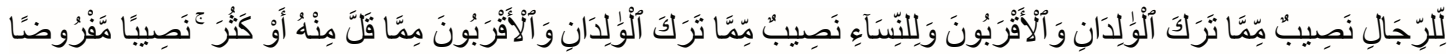
"Bagi orang laki-laki ada hak bagian dari harta peninggalan ibu-bapak dan kerabatnya. Dan bagi wanita ada hak bagian dari harta peninggalan ibu bapak dan kerabatnya, baik sedikit atau banyaknya menurut bagian yang telah ditetapkan."

Amir Syarifuddin menyebutkan bahwa didalam ketentuan kewarisan Islam yang terdapat dalam al-Qur'an lebih banyak yang telah ditentukan dari pada yang tidak ditentukanbagiannya. Sebab itu, hukum ini disebut dengan faraidh. ${ }^{12}$

Dalam istilah mawaris, faraidh digunakan sebagai suatu bagian ahli waris yang telah ditentukan oleh syara'.13

Hukum kewarisan Islam berdasarkan pada al-Qur'an dan sunnah serta ijtihad ulama'. Maka itulah, hukum kewarisan Islam ini dijadikan panduan bagi semua muslim dalam membagi warisan. Walaupun dalam penerapannya terdapat perbedaan pada beberapa daerah atau negara karena dipengaruhi latar belakang adat dan budaya.

Dalam hukum kewarisan Islam dijelaskan bahwa tidak semua orang yang meninggal bisa diambil harta warisannya. Hanya orang-orang yang memiliki hubungan darah, hubungan perkawinan, wala' atau hubungan sesama Islam yang berhak mendapatkan harta warisan. ${ }^{14}$ Adapun unsur-unsur kewarisan dalam hukum islan itu ada tiga, yaitu :

1. Muwaris adalah orang yang meninggalkan harta waris,

2. Waris adalah ahli waris yang memiliki hak mendapatkan harta waris dari muwaris,

\footnotetext{
${ }^{9}$ Amin Abdu al-Ma'bud Zaghlul, Ahkam al-Miras wa al-wasiyah..., h 6.

10Wahbbah al-Zuhaili, al-Figh al-Islamy..., h. 241.

11 Ibid., h. 47.

12 Amir Syarifuddin, Hukum Kewarisan Islam, (Jakarta: Kencana, 2004), h. 5.

${ }^{13}$ Moh. Muhibbin dan Abdul Wahid, Hukum Kewarisan Islam..., h. 9.

14Ibid., h. 175.
} 
3. Maurus adalah harta yang ditinggalkan muwaris untuk ahli warisnya. ${ }^{15}$ Dalam literatur fiqh, harta peninggalan ini sering disebut dengan istilah tirkah yang berarti sesuatu yang ditinggalkan oleh si mayit berupa harta secara mutlak. Mayoritas ahli fiqih berpesepakat bahwa maksud dari harta secara mutlak disini berupa harta benda dan hak-hak kebendaan. ${ }^{16}$

\section{B.2. Bagian Istri Dalam Hukum Kewarisan Islam}

Disebutkan dalam surat an-Nisa' ayat 7:

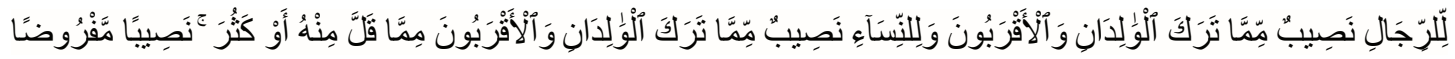

"Bagi orang laki-laki ada hak bagian dari harta peninggalan ibu-bapak dan kerabatnya dan bagi perempuan ada hak bagian (pula) dari harta peninggalan ibu-bapak dan kerabatnya, baik sedikit atau banyak menurut bagian yang telah ditetapkan."

Ayat tersebut dengan jelas menyebutkan bahwa laki-laki dan perempuan memiliki hak waris. Dan ini sebagai bukti bahwa Islam itu adil, tidak membedabedakan antara laki-lakii dan perempuan. Hal ini jelas berbeda terbalik dengan kondisi zaman pra Islam, yakni zaman jahiliyah.

Pada masa jahiliyah, seorang perempuan termasuk istri tidaklah mendapat warisan. Namun bisa jadi istri yang akan menjadi harta warisan. Islam hadir mengangkat derajat perempuan, dengan memberikannya bagian yang pasti dan masuk pada kelompok ashabul furudhtanpa ada yang bisa menghalangi haknya sebagai istri. Dan juga mengharamkan istri dijadikan sebagai harta warisan. Sebagaimana yang disebutkan dalam surat an-Nisa' ayat 19:

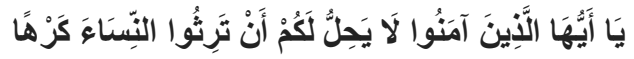

"Hai orang-orang yang beriman, tidak halal bagimu mewarisi wanita dengan jalan paksa."

Dalam fiqh mawaris, istri mendapatkan bagian 1/4 jika dengan almarhum suaminya tersebut tidak memiliki anak ataupun suaminya tersebut tidak memiliki anak, baik dari istri tersebut ataupun dari istri lainnya. Namun bila terdapat anak, maka istri akan mendapatkan 1/8.17 Bagian istri ini adalah bagian pasti yang sudah disebutkan dalam al-Qur'an surat an-Nisa' ayat 12:

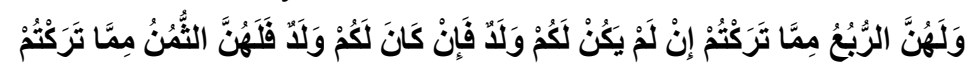

"Para isteri mendapatkan seperempat harta yang kamu (suami) tinggalkan jika kamu tidak memiliki anak. jika kamu memiliki anak, maka para istri memperoleh seperdelapan dari harta yang kamu tinggalkan."

\section{B.3. Warisan dalam Kompilasi Hukum Islam}

Kompilasi hukum Islam adalah sekumpulan materi hukum Islam yang ditulis pasal demi pasal, berjumlah 229 pasal, dan terdiri atas tiga bagian materi hukum, yaitu :18

${ }^{15}$ Amin Abdu al-Ma'bud Zaghlul, Ahkam al-Miras wa al-wasiyah..., h. 79.

16Ibid., h. 14.

17Ibid., h. 108.

${ }^{18}$ Wahbbah al-Zuhaili, al-Figh al-Islamy..., h. 176. 
1. Hukum perkawinan sebanyak 170 pasal

2. Hukum kewarisan, wasiat dan hibah sebanyak 44 pasal

3. Hukum perwakafan sebanyak 14 pasal.

Mayoritas penduduk Indonesia beragama Islam, namun dalam penerapan kesehariannya masih dipengaruhi oleh politik Islam pemerintahan Hindia Belanda yang banyak menggunakan hukum adat. Kemudian dibiarkan berlanjut oleh pemerintah Republik Indonesia, sehingga banyak masalah yang dihadapi Peradilan Agama.

Sebenarnya persoalan pokok yang terjadi adalah adanya hakim Peradilan Agama yang menyamakan antara syariah dengan fiqh. Sehingga, ketika ia memutuskan suatu perkara, ia akan merujuk kepada kitab fiqh yang dominan dan sesuai dengan madzhab yang dianut.

Selain itu, zaman dahulu wawasan para hakim Peradilan Agama mengenai fiqh Islam di Indonesia masih terpaku pada hukum madzhab syafi'iyah saja. Karena mayoritas umat Islam di Indonesia menganut madzhab Syafi'i. Hal ini menimbulkan munculnya berbagai putusan Peradilan Agama yang berbeda-beda untuk perkara yang sama.Sehingga tampak adanya ketidakpastian hukumyang dapat menyebabkan masyarakat pencari keadilan terhadap Peradilan agamatidak ada kepercayaan lagiterhadap Peradilan Agama. ${ }^{19}$

Sebab itulah adanya Kompilasi Hukum Islam yang tidak hanya merujuk pada satu madzhab sangat diperlukan sebagai hukum positif untuk landasan rujukan setiap keputusan Peradilan Agama. Supaya mendapatkan keseragaman keputusan hukum di Peradilan Agama. Dan terciptanya keadilan yag merata untuk semua umat Islam di negeri ini.

Usaha untuk mendekatkan orang Islam dengan keislamannya terus menerus dilakukan. Diantaranya adalah mendekatkan dan menerapkan hukum Islam dalam bidang kewarisan. Sebab menurut hukum positif Indonesia, jika orang Islam akan membagi warisan, mereka tidak harus tunduk pada hukum kewarisan Islam. Mereka masih diberi kebebasan untuk memilih pranata hukum lain, yaitu hukum kewarisan adat dan hukum kewarisan berdasarkan KUHP Perdata.

Hal ini berbanding terbalik dengan hukum perkawinan. Selain Kompilasi Hukum Islam, hukum perkawinan di Indonesia juga diatur dalam Undang-Undang Nomor 1 tahun 1974. Disebutkan dalam UU Nomor 1 tahun 1974 pasal 2 ayat 1 bahwa orang Islam yang akan melangsungkan perkawinan harus tunduk pada ketentuan-ketentuan perkawinan menurut hukum perkawinan Islam. ${ }^{20}$

Pada pasal 171 dalam Kompilasi Hukum Islam dijelaskan bahwa :21

1. Hukum kewarisan adalah hukum yang mengatur tentang pemindahan hak pemilikan harta peninggalan (tirkah) pewaris, menentukan siapasiapa yang berhak menjadi ahli waris dan berapa bagiannya masingmasing.

${ }^{19}$ Wahbbah al-Zuhaili, al-Figh al-Islamy..., h. 175,

20Ibid., h. 178

21Tim Permata Press, Kompilasi Hukum Islam (KHI), (Permata Press), h. 53. 
2. Pewaris adalah orang yang pada saat meninggalnya atau yang dinyatakan meninggal berdasarkan putusan Pengadilan beragama Islam, meninggalkan ahli waris dan harta peninggalan.

3. Ahli waris adalah orang yang pada saat meninggal dunia mempunyai hubungan darah atau hubungan perkawinan dengan pewaris, beragama Islam dan tidak terhalang karena hukum untuk menjadi ahli waris.

4. Harta peninggalan adalah harta yang ditinggalkan oleh pewaris baik yang berupa harta benda yang menjadi miliknya maupun hak-haknya.

5. Harta warisan adalah harta bawaan ditambah bagian dari harta bersama setelah digunakan untuk keperluan pewaris selama sakit sampai meninggalnya, biaya pengurusan jenazah (tajhiz), pembayaran utang dan pemberian untuk kerabat.

Di Indonesia, struktur masyarakatnya berbeda dengan masyarakat Arab, yang mana tidak ada perbedaan harta. Sedangkan dalam kehidupan masyarakat Indonesia membedakan harta keluarga atau dalam sebuah rumah tangga ada 4 macam, yaitu :22

1. Harta bawaan masing-masing dari suami dan istri yang didapatkan sebelum perkawinan atas usaha sendiri

2. Harta yang dibawa ketika menikah oleh suami atau istri, yakni bisa berupa harta pemberian untuk kedua mempelai sebagai modal usaha atau berupa tempat kediaman ataupun lainnya.

3. Harta yang didapatkan oleh suami atau istri selama perkawinan berupa pemberian (hibbah) ataupun warisan dari orang tua / keluarga.

4. Harta yang didapatkan selama perkawinan atas usaha bersama atau salah satu pihak. di jawa biasa disebut harta gono gini.

Dari keempat macam harta tersebut, jikalau salah satu dari pasangan suami istri meninggal dunia, maka harta no.1, 2 dan 3 akan kembali kepada masing-masing pihak.Hal ini sesuai dengan aturan Kompilasi Hukum Islam dalam bab XIII tentang harta kekayaan dalam perkawinanpasal 85,86 , dan 87 . Adapun bunyinya adalah $: 23$

Pasal 85 :

Adanya harta bersama dalam perkawinan itu tidak menutup kemungkinan adanya harta milik masing-masing suami atau istri.

Pasal 86:

1. Pada dasarnya tidak ada percampuran antara harta suami dan harta istri karena perkawinan.

2. Harta istri tetap menjadi hak istri dan dikuasai penuh olehnya, demikian juga harta suami tetap menjadi hak suami dan dikuasai penuh olehnya.

Pasal 87:

22Moh. Muhibbin dan Abdul Wahid, Hukum Kewarisan Islam..., h. 58

23Tim Permata Press, Kompilasi Hukum Islam (KHI)..., h. 28. 
1. Harta bawaan dari masing-masing suami dan istri dan harta yang diperoleh masing-masing sebagai hadiah atau warisan adalah dibawah penguasaan masing-masing, sepanjang para pihak tidak menentukan lain dalam perjanjian perkawinan.

2. Suami dan istri mempunyai hak sepenuhnya untuk melakukan perbuatan hukum atas harta masing-masing berupa hibah, hadiah, sodaqoh atau lainnya.

Adapun harta yang no.4 akan menjadi harta waris. Di jawa, harta gono gini ini akan dibagi menjadi 2:1 atau dikenal dengan istilah sepikul segendongan yakni sepikul atau 2 bagian untuk suami dan segendongan atau 1 bagian untuk istri. ${ }^{24}$

Namun dalam Kompilasi Hukum Islam, harta bersama yang didapatkan selama perkawinan ini akan dibagi rata, yaitu 1/2 untuk suami dan $1 / 2$ untuk istri. Sebagaimana yang disebutkan pada pasal 96 ayat 1 dalam Kompilasi Hukum Islam, yang berbunyi :25

"Apabila terjadi cerai mati, maka separuh (1/2) harta bersama menjadi hak pasangan hidup yang lebih lama."

\section{B.4. Bagian istri atau janda dalam Kompilasi Hukum Islam}

Disebutkan dalam Kompilasi Hukum Islam pasal 180 yang berbunyi :26 "Janda mendapat seperempat bagian bila pewaris tidak meninggalkan anak, dan bila pewaris meninggalkan anak, maka janda mendapat seperdelapan bagian."

Dari pasal tersebut diketahui bahwa istri yang ditinggal mati suaminya atau biasa disebut janda, akan mendapatkan bagian $1 / 4$ bilamana tidak terdapat anak dari mereka atau dari suami dengan istri lainnya. Namun bila sebaliknya, maka bagian istri berkurang menjadi $1 / 8$.

\section{B.5. Perbandingan Hukum Kewarisan Islam dengan Kompilasi Hukum Islam}

Hukum kewarisan Islam bersumber pada hukum Islam yang mana pengambilan hukumnya berdasarkan pada al-Qur'an, al-Sunnah dan juga ijtihad para ulama'.

Adapun Kompilasi Hukum Islam juga sama dengan hukum kewarisan Islam yang bersumber pada hukum Islam dan pengambilan hukumnya berdasarkan pada al-Qur'an, al-Sunnah dan juga ijtihad para ulama' Islam di dunia pada umumnya dan ulama' Indonesia khususnya, yang tentunya ulama' Indonesia dalam membuat kepastian hukum dipengaruhi latar belakang kehidupan masyarakat Indonesia.

Didalam beberapa literatur fiqh yang berkaitan dengan masalah kewarisan tidak pernah disinggung tentang harta suami dan harta istri yang akan dibagikan kepada ahli waris jika ia meninggal dunia.Semua harta seakan milik suami, namun apa yang dimiliki suami juga menjadi milik istri. Sebab suami memiliki kewajiban

${ }^{24}$ Moh. Muhibbin dan Abdul Wahid, Hukum Kewarisan Islam..., h. 59.

25Tim Permata Press, Kompilasi Hukum Islam (KHI)..., h. 30.

26Ibid., h. 56. 
menafkahi istri dan anak-anaknya atau keluarganya. ${ }^{27} \mathrm{Hal}$ ini berlandaskan pada alQur' an surat an-Nisa' ayat 34 :

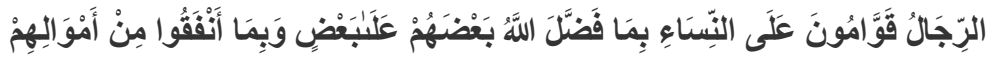

"Laki-laki bertanggungjawab atas perempuan, oleh karena Allah melebihkan sebagian mereka (laki-laki) atas sebagian yang lain (perempuan) dan karena mereka (laki-laki) telah menafkahkan sebagian harta mereka."

Disebutkan pula dalam sebuah hadis yang diriwayatkan dari sayyidah 'Aisyah ra bahwa Hindun binti 'utbah istri dari Abu Sufyan datang mengadu kepada Rasulullah SAW dengan berkata : “Wahai Rasululloh, sesungguhnya Abu Sufyan adalah seorang suami yang pelit. Dia tidak memberi untukku dan anakanakkuu nafkah yang mencukupi kecuali jikalau aku mengambil uangnya tanpa sepengetahuannya." Rasulullah SAW pun bersabda : "Ambillah dari hartanya yang bisa mencukupi kebutuhanmu dan anak-anakmu dengan kadar sepatutnya." HR. Bukhari No.5364. ${ }^{28}$

Dari hadis tersebut, tampak jelas bahwa dalam harta suami terdapat hak istri didalamnya karena adanya kewajiban suami menafkahi istri dan anak-anaknya.

Struktur masyarakat Indonesia jelas memiliki perbedaan dengan masyarakat Arab. Di negara arab, seorang perempuan tidak sebebas perempuan Indonesia dalam bekerja. Mayoritas perempuan-perempuan Indonesia berkarier atau bekerja, sama dengan laki-laki. Selain itu, harta pasangan suami istri dalam kehidupan berumah tangga di Indonesia diklasifikasikan sendiri, sesuai dengan perolehannya kapan, dari mana dan untuk siapa, (istri atau suami).

Pendapat beberapa ulama' Indonesia dalam menentukan klasifikasi harta yang diperoleh dari hasil pendapatan milik bersama (suami istri) yang masing-masing mempunyai bagian dari harta tersebut dengan mendasarkan pada al-Quran sebagai sumber hukum Islam dalam surat an-Nisa' ayat 32:29

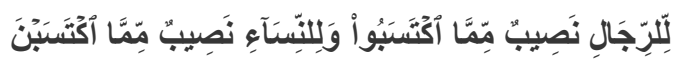

"Bagi laki-laki ada bagian dari apa yang mereka usahakan dan bagi perempuan juga ada

\begin{tabular}{|c|c|c|}
\hline No. & Huk & HAd \\
\hline 1. & $\begin{array}{l}\text { 1/4 bagian bila tidak memiliki } \\
\text { anak dengan almarhum suami } \\
\text { tersebut atau suami tersebut tidak } \\
\text { memiliki anak dengan istri } \\
\text { lainnya. } \\
1 / 8 \text { bagian bila memiliki anak dari } \\
\text { almarhum suami tersebut atau } \\
\text { almarhum suami tersebut }\end{array}$ & $\begin{array}{l}\text { 1/4 bagian bila tidak memiliki anak } \\
\text { dengan almarhum suami tersebut atau } \\
\text { suami tersebut tidak memiliki anak } \\
\text { dengan istri lainnya. } \\
1 / 8 \text { bagian bila memiliki anak dari } \\
\text { almarhum suami tersebut atau } \\
\text { almarhum suami tersebut memiliki } \\
\text { anak dari istri lainnya. }\end{array}$ \\
\hline & Tidak ada perbedaan antara harta & Tidak ada percampuran harta antara \\
\hline
\end{tabular}
bagian yang mereka usahakan."

27Moh. Muhibbin dan Abdul Wahid, Hukum Kewarisan Islam..., h. 57.

28Salmah, Nafkah Dalam Perspektif Hadis, dalam Jurnal Ilmiah Juris Vol.13, 2014, h. 96.

${ }^{29}$ Ibid., h. 58. 


\begin{tabular}{|l|l|l|l|}
\hline & istri dan suami & harta bawaan suami dan istri. \\
\hline 3. & - & $\begin{array}{l}\text { Mendapat 1/2 bagian dari harta } \\
\text { bersama }\end{array}$ \\
\hline
\end{tabular}

\section{Simpulan}

Dari berbagai uraian diatas dapat disimpulkan bahwa dalam hukum kewarisan Islam: 1) tidak ada perbedaan harta yang didapat antara suami istri, baik sebelum dan sesudah menikah, 2) istri mendapatkan $1 / 4$ bagian bila tidak memiliki anak dari almarhum suami tersebut atau almarhum suami tersebut tidak memiliki anak dari istri lainnya. Namun bila sebaliknya,maka mendapat $1 / 8$ bagian. Sedangkan, dalam Kompilasi Hukum Islam: 1) tidak ada percampuran harta antara harta suami dan istri kecuali harta atas usaha bersama atau usaha salah satu pasangan sebagai pendapatan hidup, 2) istri tetap memiliki harta bawaannya baik sebelum atau setelah menikah dan mendapatkan harta warisnya $1 / 4$ atau $1 / 8$ dengan melihat ada atau tidak anak ditambah $1 / 2$ dari harta bersamanya selama menikah.

\section{Referensi:}

Abdurrahman.1992. Kompilasi Hukum Islam di Indonesia. Jakarta: Akademika Pressindo.

al-Jurjani,Muhammad.Kitab al-Ta'rifat . Singapore, Jeddah : al-Haramian.

al-Zuhaili, Wahbbah.2008. al-Figh al-Islamy wa adillatuh. Damaskus: Dar al-Fikr.

Ash-Shiddieqy, Teungku Muhammad Hasbi.2001. Figh Mawaris. Semarang: Pustaka Rizki Putra.

Muhibbin, Moh. dan Abdul Wahid.2019. Hukum Kewarisan Islam Sebagai Pembaruan Hukum Positif di Indonesia. Jakarta: Sinar Grafika.

Press,Tim Permata.Kompilasi Hukum Islam (KHI). Permata Press.

Salmah, 2014. Nafkah Dalam Perspektif Hadis, dalam jurnal ilmiah Juris volume 13. Syarifuddin, Amir. 2004. Hukum Kewarisan Islam. Jakarta: Kencana.

Zaghlul, Amin Abdu al-Ma'bud. 2009. Ahkam al-Miras wa al-wasiyah fi Syari'ah alIslamiyah. Kairo: Nabil. 